\title{
Current knowledge on exosome biogenesis and release
}

\author{
Nina Pettersen Hessvik ${ }^{1,2} \cdot$ Alicia Llorente ${ }^{1,2}$
}

Received: 21 April 2017 / Revised: 22 June 2017 / Accepted: 13 July 2017 / Published online: 21 July 2017

(C) The Author(s) 2017. This article is an open access publication

\begin{abstract}
Exosomes are nanosized membrane vesicles released by fusion of an organelle of the endocytic pathway, the multivesicular body, with the plasma membrane. This process was discovered more than 30 years ago, and during these years, exosomes have gone from being considered as cellular waste disposal to mediate a novel mechanism of cell-to-cell communication. The exponential interest in exosomes experienced during recent years is due to their important roles in health and disease and to their potential clinical application in therapy and diagnosis. However, important aspects of the biology of exosomes remain unknown. To explore the use of exosomes in the clinic, it is essential that the basic molecular mechanisms behind the transport and function of these vesicles are better understood. We have here summarized what is presently known about how exosomes are formed and released by cells. Moreover, other cellular processes related to exosome biogenesis and release, such as autophagy and lysosomal exocytosis are presented. Finally, methodological aspects related to exosome release studies are discussed.
\end{abstract}

Keywords Autophagy $\cdot$ Endosomes $\cdot$ Exosomes · Extracellular vesicles $\cdot$ Lysosomes $\cdot$ Microvesicles $\cdot$ MVB biogenesis $\cdot$ MVBs $\cdot$ Release $\cdot$ Secretion

Alicia Llorente

Alicia.Martinez.Llorente@ rr-research.no

1 Department of Molecular Cell Biology, Institute for Cancer Research, Oslo University Hospital, The Norwegian Radium Hospital, 0379 Oslo, Norway

2 Centre for Cancer Biomedicine, University of Oslo, 0379 Oslo, Norway

\author{
Abbreviations \\ EM Electron microscopy \\ ESCRT Endosomal sorting complex required for \\ transport \\ EVs Extracellular vesicles \\ FC Flow cytometry \\ ILV Intraluminal vesicle \\ MVB Multivesicular body \\ NTA Nanoparticle tracking analysis \\ SNAREs Soluble $N$-ethylmaleimide-sensitive factor \\ attachment protein receptors \\ WB Western blot
}

\section{Introduction}

Extracellular vesicles (EVs) were first observed 50 years ago in plasma by Wolf, who referred to them as "platelet dust" [1]. Since then, all biological fluids tested have been shown to contain vesicles, and also in vitro grown cell lines have been shown to release vesicles to different extents $[2,3]$. These vesicles have received different names during the years, but today are often collectively referred as EVs. Three main types of EVs have been described based on their mechanism of release and size: exosomes (less than $150 \mathrm{~nm}$ in diameter), microvesicles/shedding particles and apoptotic bodies (both considered to be larger than $100 \mathrm{~nm}$ ). The last two types of vesicles are released directly from the plasma membrane in living and dying cells, respectively, and will not be further discussed here. This review deals with the smallest of the family, the exosomes, which are vesicles that are released to the extracellular environment after fusion of late endosomes/multivesicular bodies (MVBs) with the plasma membrane (Fig. 1). This process was first visualized in rat reticulocytes in 1983 [4], 


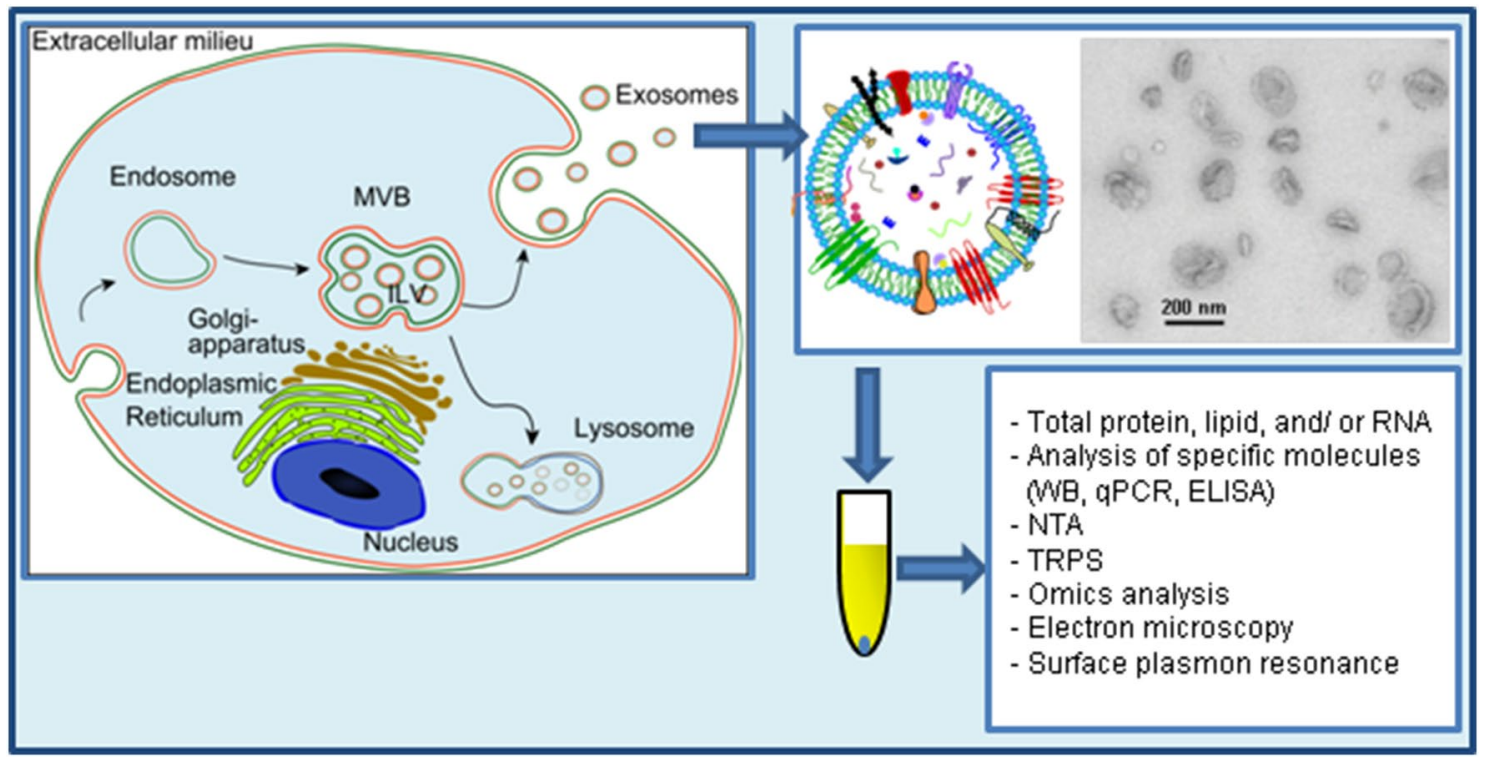

Fig. 1 Study of exosome release. Exosomes are released after fusion of MVBs with the plasma membrane. Exosomes have a complex composition of protein, nucleic acids, lipids and other metabolites. Due to their small size $(<150 \mathrm{~nm}$ in diameter), exosomes are best visualized by electron microscopy. Though some commonly used electron microscopy methods artificially show exosomes as cup-shaped structures, exosomes are round structures. Exosomes are isolated from cell-conditioned media by several protocols that aim to concen-

and then in sheep reticulocytes in 1985 [5]. Rose Johnstone, a pioneer in the field, chose the term "exosome" in 1987 because "the process seemed to be akin to reverse endocytosis, with internal vesicular contents released in contrast to external molecules internalized in membrane-bound structures" $[6,7]$. Further insight into this process has, however, mainly been acquired in recent years [8].

Initially, exosomes were proposed to represent cellular waste [7], and recent data also support the idea of exosomes as an alternative way of eliminating waste products to maintain cellular homeostasis $[9,10]$. In addition, these vesicles are suggested to play a role in intercellular communication and have been associated with numerous physiological and pathological functions $[2,11,12]$. Interestingly, exosomes from cancer cells have been shown to promote angiogenesis, modulate the immune system and remodel the surrounding parenchymal tissue, all factors supporting tumor progression (reviewed in [13]). In particular, exosomes have been shown to participate in the generation of the pre-metastatic niche [14-16].

To release exosomes, several cellular steps need to be completed; formation of intraluminal vesicles (ILVs) in MVBs, transport of MVBs to the plasma membrane and fusion of MVBs with the plasma membrane. Several molecules have been implicated in these processes, but due to methodological challenges, it is not easy to distinguish trate the exosomal signal to be analyzed and to avoid contaminating molecules such as proteins that are secreted by other mechanisms. Once isolated, exosomes can be analyzed by several methods such as the ones included in this figure. TRPS tunable resistive pulse sensing, NTA nanoparticle tracking analysis. The figure contains parts reprinted from the Ph.D. degree of Santosh Phuyal, University of Oslo, with permission from the author

them experimentally, and in many studies it is not clear at which step the investigated molecule/factor operates (Fig. 2). Another important question is whether all MVBs or only specific populations can fuse with the plasma membrane. In agreement with the latter possibility, it has been shown that in B-lymphocytes two pools of MVBs can be identified based on their cholesterol content, and that only MVBs with high cholesterol levels are able to fuse with the plasma membrane and release exosomes [17]. Moreover, EGF and its receptor have been shown to reach a subpopulation of MVBs that are distinct from morphologically identical vacuoles labeled with BMP (bismonoacyl glycerophosphate), also called LBPA (lysobisphosphatic acid) [18], a late endosomal marker [19]. Interestingly, several studies show that exosomes secreted from the apical and basolateral side of polarized cells differ in composition [20-22], thus also supporting the existence of different MVB populations. Furthermore, it would be interesting to learn more about the kinetics of exosome release, for example how many MVBs per hour fuse with the plasma membrane. Measurements of total exosomal protein levels and western blot (WB) analysis of specific proteins indicate that cells only release a small percentage of their content via exosomes. However, as discussed later, the extent of exosome release is cell-dependent, and it can be regulated by different cellular conditions or external factors. 
Fig. 2 Molecules shown to affect exosome biogenesis and/ or release. The process that leads to secretion of exosomes can be divided in three steps; exosome biogenesis, transport of MVBs to the plasma membrane and fusion of MVBs with the plasma membrane. The step affected, or likely to be affected, by each molecule is indicated on the figure

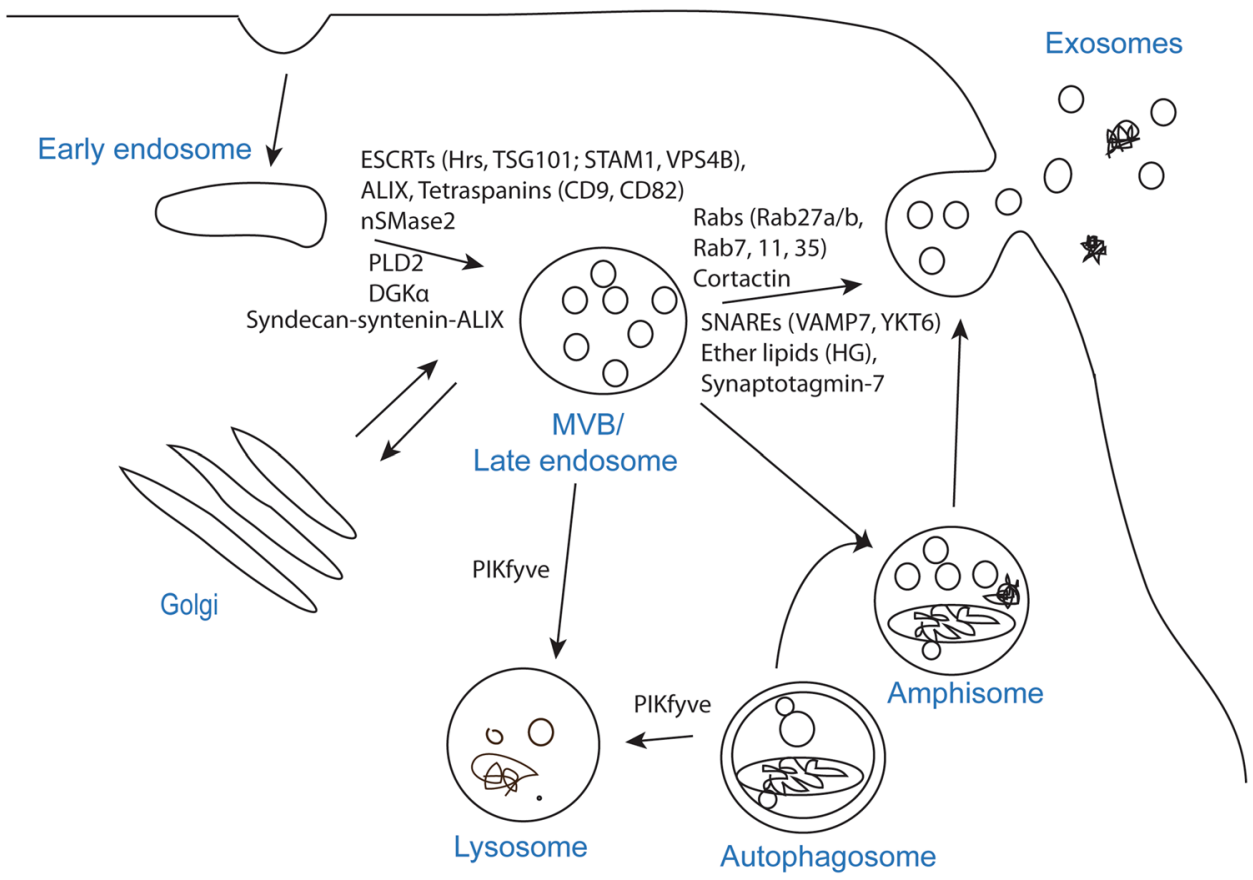

Mass spectrometry-based proteomics and lipidomics analyses have been useful to characterize the proteome and lipidome of exosomes, respectively [23-25]. It can be expected that the composition of exosomes reflects to some extent the composition of MVBs. In fact, proteins associated with MVBs such as several endosomal sorting complex required for transport (ESCRT) proteins or CD63 have been found in exosomes, as can been seen in databases that compile information about the molecular composition of exosomes [26, 27]. Knowledge on the composition of exosomes can give us clues about the machinery involved in their release. However, due to the complex composition of exosomes, it is difficult to identify these molecules. In addition, molecules involved in the release of exosomes do not necessarily need to be incorporated into them.

In this review, the process that ends with the release of exosomes has been divided into several steps (see above) for simplicity. However, it should be mentioned that in some cases the roles of a molecule in a specific step is not completely understood. In addition, a specific molecule can be involved in more than one step along the pathway that leads to the secretion of exosomes. This review also includes a section about methodological issues related to exosome release studies, since they might explain discrepant findings. It is also important to mention that the term "exosomes" is often used to refer to the pellet obtained after $100,000 \times g$ ultracentrifugation. Although this pellet is probably enriched in exosomes, it might also contain small microvesicles as well as protein aggregates. In fact, it was recently suggested that this pellet should be referred to as small EVs (sEVs), since it was shown to contain different vesicle populations [28]. Therefore, one should be aware that changes in this pellet may not only reflect changes in exosome release.

\section{Exosome biogenesis}

Exosome biogenesis starts within the endosomal system; early endosomes mature into late endosomes or MVBs, and during this process the endosomal membrane invaginates to generate ILVs in the lumen of the organelles [29]. The ESCRT machinery is important in this process. ESCRT consist of four different protein complexes; ESCRT-0, -I, -II, -III and the associated AAA ATPase Vps4 complex [30]. The most thorough study of ESCRTs in exosome biogenesis was an interesting RNAi screen targeting 23 ESCRT and ESCRT-associated proteins in HeLa cells [31]. After shRNA transfection, secreted exosomes were trapped on anti-CD63-beads and detected by anti-CD81 and antiHLA-DR (MHC II) antibodies using flow cytometry (FC). In this screening, seven ESCRT proteins that affected exosome secretion were identified. Depletion of the ESCRT-0 proteins Hrs and TSG101, and the ESCRT-I protein STAM1 reduced the secretion of exosomes (Table 1; Fig. 2). Knockdown of the ESCRT-III and associated proteins CHMP4C, VPS4B, VTA1 and ALIX increased exosome secretion. When the role of four proteins was verified in exosomes isolated by ultracentrifugation and analyzed by WB, it was found that Hrs, TSG101 and STAM1 depletion decreased exosome secretion, whereas VPS4B knockdown increased it [31]. Silencing of ALIX seemed to change 
Table 1 Molecules shown to be involved in exosome biogenesis and/or release

\begin{tabular}{|c|c|c|c|}
\hline Protein/lipid/modification & Cell line & Secretion quantified by & References \\
\hline Hrs & $\begin{array}{l}\text { DCs, HEK293, SCC61, SCC25-H1047R } \\
\text { HNSCC, HeLa }\end{array}$ & $\begin{array}{l}\text { Ubiquitinated proteins, TSG101, VPS4B, } \\
\text { Evi, Wnt3A (WB), NTA, CD81/HLA-DR } \\
\text { (FC), MHC II, HSC70, CD63 (WB) }\end{array}$ & {$[31-34]$} \\
\hline STAM1 & HeLa & $\begin{array}{l}\text { CD81/HLA-DR (FC), MHC II, HSC70, } \\
\text { CD63 (WB) }\end{array}$ & {$[31]$} \\
\hline TSG101 & HeLa & $\begin{array}{l}\text { CD81/HLA-DR (FC), MHC II, HSC70, } \\
\text { CD63 (WB) }\end{array}$ & {$[31]$} \\
\hline CHMP4C & HeLa & CD81/HLA-DR (FC) & {$[31]$} \\
\hline ALIX & HeLa, DCs, MCF-7 & $\begin{array}{l}\text { CD81/HLA-DR (FC), CD63, HSP70, syn- } \\
\text { decan (WB), NTA }\end{array}$ & {$[31,35]$} \\
\hline VTA1 & HeLa & CD81/HLA-DR (FC) & {$[31]$} \\
\hline VPS4 & HeLa & $\begin{array}{l}\text { CD81/HLA-DR (FC), MHC II, HSC70, } \\
\text { CD63 (WB) }\end{array}$ & {$[31]$} \\
\hline Syntenin & MCF-7 & CD63, HSP70, syndecan (WB), NTA & {$[35]$} \\
\hline Syndecan & MCF-7 & CD63, HSP70, ALIX, syntenin (WB), NTA & {$[35]$} \\
\hline CD9 & HEK293, BMDCs & $\beta$-Catenin, flotillin-1 (WB) & {$[40]$} \\
\hline CD82 & HEK293 & $\beta$-Catenin (WB) & {$[40]$} \\
\hline CD63 & HEK293 & NTA & {$[42]$} \\
\hline LMP1 & HEK293 & $\begin{array}{l}\text { NTA, acetylcholinesterase activity, Alix, } \\
\text { HSC70, CD63, and TSG101 (WB) }\end{array}$ & {$[43]$} \\
\hline Tspan8 & Adenocarcinoma cells & $\begin{array}{l}\text { mRNA microarray, RT-qPCR, proteomics, } \\
\text { WB }\end{array}$ & [41] \\
\hline Synaptotagmin-7 & SCC61, SCC25-H1047R HNSCC & NTA & [34] \\
\hline VAMP7 & K562 & Acetylcholinesterase activity & [94] \\
\hline YKT6 & HEK293 and A549 & TSG101, WNT3A and VPS26/35 (WB) & {$[33,95]$} \\
\hline Syntaxin 1A & Drosophila S2 & Evi (WB) & {$[82]$} \\
\hline PKM2 & A549, HeLa & NTA & [96] \\
\hline SNAP-23 & A549 & NTA & {$[96]$} \\
\hline RalA and RalB & $4 \mathrm{~T} 1$ & $\begin{array}{l}\text { EM, ALIX, CD63, HSC70 and TSG101 } \\
\text { (WB) }\end{array}$ & [97] \\
\hline Rab2b & HeLa & HLA-DR (FACS-assay) & {$[83]$} \\
\hline Rab5a & HeLa & HLA-DR (FACS-assay) & [83] \\
\hline Rab9a & HeLa & HLA-DR (FACS-assay) & {$[83]$} \\
\hline Rab7 & MCF-7, HUVEC & $\begin{array}{l}\text { CD63, syntenin and syndecan (WB), miR- } \\
143 \text { (qPCR) }\end{array}$ & {$[35,89]$} \\
\hline Rab11 & K562, Drosophila S2 & $\begin{array}{l}\text { Transferrin receptor, Lyn, HSC70 and Evi } \\
\text { (WB) }\end{array}$ & {$[81,82]$} \\
\hline $\operatorname{Rab} 27 \mathrm{a}$ & $\begin{array}{l}\text { HeLa, 4T1, TS/A, B-16-F-10, SK-Mel-28, } \\
\text { SCC61, SCC25-H1047R HNSCC, Du145 }\end{array}$ & $\begin{array}{l}\text { HLA-DR (FACS-assay), total protein, HLA- } \\
\text { DR, HSC70, TSG101, CD63, ALIX and } \\
\text { LAMP2 (WB), NTA, CD9 (ELISA) }\end{array}$ & {$[14,34,83,86,87]$} \\
\hline $\operatorname{Rab} 27 b$ & HeLa, HUVEC & $\begin{array}{l}\text { HLA-DR (FACS-assay), total protein, HLA- } \\
\text { DR, HSC70 and TSG101 (WB), miR-143 } \\
\text { (qPCR) }\end{array}$ & {$[83,89]$} \\
\hline Rab35 & Oli-neu & PLP (WB) & {$[84,85]$} \\
\hline Citron kinase & HeLa, 293T & HSC70, CD82, Lamp-1 (WB) & [91] \\
\hline Cortactin & SCC61 & NTA, TSG101, CD63 and flotillin-1 (WB) & [79] \\
\hline ISGylation & Jurkat $\mathrm{T}$ and HEK293 & $\begin{array}{l}\text { CD63, CD81, TSG101 and flotillin (WB), } \\
\text { NTA }\end{array}$ & {$[77]$} \\
\hline SIMPLE & COS & $\begin{array}{l}\text { Fluorescence of LactC2-RFP, NTA, CD63, } \\
\text { ALIX (WB) }\end{array}$ & {$[44]$} \\
\hline nSMase2 & Oli-neu, PC-3, HEK293, J77 & $\begin{array}{l}\text { PLP, EGFP-CD63 (WB), miR-16, miR-146a } \\
\text { (qPCR), total protein, CD81 (WB) }\end{array}$ & [47-49] \\
\hline DGK $\alpha$ & J-HM1-2.2 & CD63, Lamp-1, FasL, (WB) & {$[55]$} \\
\hline
\end{tabular}


Table 1 (continued)

\begin{tabular}{|c|c|c|c|}
\hline Protein/lipid/modification & Cell line & Secretion quantified by & References \\
\hline PLD2 & RBL-2H3, MCF-7 & $\begin{array}{l}\text { Bodipy-ceramide label (FACS), syntenin, } \\
\text { ALIX, CD63 (WB) }\end{array}$ & {$[52,53]$} \\
\hline ARF6 & MCF-7 & Syntenin, ALIX, CD63, SDC1CTF (WB) & {$[53]$} \\
\hline Cholesterol & Oli-neu, PC-3 & $\begin{array}{l}\text { Flotillin-2, ALIX, EGFP-CD63, PLP-myc, } \\
\text { caveolin-1, Lamp-1 (WB) }\end{array}$ & {$[100,101]$} \\
\hline Ether lipid (hexadecylglycerol) & PC-3 & NTA, total protein & [98] \\
\hline V-ATPase & HeLa & EM, CD63, ALIX, TSG101 (WB) & [105] \\
\hline Tetherin & HeLa & EM, CD63, ALIX, TSG101 (WB) & [105] \\
\hline Hypoxia & MCF-7, SKBR3, MDA-MB 231 & NTA, CD63 (WB) & [110] \\
\hline Irradiation & LNCaP, 22Rv1, PBMC & $\begin{array}{l}\text { Vybrant DiI (fluorescent staining), B7-H3 } \\
\text { (WB), NTA, total protein }\end{array}$ & {$[107,108]$} \\
\hline Cisplatin & A549 & Total protein & [109] \\
\hline PIKfyve & $\mathrm{PC}-3$ & NTA, total protein, MS-proteomics & {$[10]$} \\
\hline ER stress (tunicamycin) & MEFs & qNano & [111] \\
\hline Autophagy (starvation) & K562 & Acetylcholinesterase activity, HSC70 (WB) & [113] \\
\hline ATG12-ATG3 & MEFs & $\begin{array}{l}\text { Total protein, ALIX, TSG101, GAPDH, } \\
\text { HSC70 (WB) }\end{array}$ & [116] \\
\hline Autophagy (ATG7) & DCs & GAPDH (WB) & [114] \\
\hline $\begin{array}{l}\text { Intracellular calcium (monen- } \\
\text { sin, A23187, ionomycin) }\end{array}$ & K562, oligodendrocytes & $\begin{array}{l}\text { HSC70 (WB), acetylcholinesterase activity, } \\
\text { PLP (WB) }\end{array}$ & {$[102,103]$} \\
\hline
\end{tabular}

The methods that were used for exosome quantification in each study are listed

the protein composition of exosomes rather than to affect their secretion. This could indicate that ALIX affects cargo loading and/or the subtypes of MVBs that are destined for secretion. However, the authors showed that ALIX depletion in dendritic cells (DCs) decreased exosome secretion in half of the donors.

The ESCRT-0 protein Hrs has in addition been shown to play a role in exosome secretion in three other independent studies [32-34]. In the first study, Hrs-depleted DCs were shown to secrete less exosomes, measured as exosomal level of ubiquitinated proteins, TSG101 and VPS4B [32]. Later, Hrs depletion in HEK293 cells was shown to reduce exosomal Wnt3A and Evi secretion [33]. In agreement with this, Hoshino et al. showed by Nanoparticle Tracking Analysis (NTA) that knockdown of Hrs decreased exosome secretion from head and neck squamous cell carcinoma cells [34].

It has been shown that the sorting of syndecans, membrane proteins carrying heparan sulfate chains, in syntenin-ALIX exosomes is mediated by their binding to syntenin. Syntenin is a multivalent soluble protein that also binds ALIX, thus establishing a link between syndecans and the ESCRT machinery [35]. Interesting, this study revealed that in addition to sorting, the interaction between syntenin and ALIX also facilitates ILV formation [35]. The same group later showed that heparanases trim the heparan sulfate side chains of syndecans thus facilitating the formation of syndecan clusters that might stimulate the binding to syntenin [36]. Interestingly, heparanase stimulates the sorting of CD63 too, indicating that the sorting of these two molecules might be related [36]. It should be mentioned that the syndecan-syntenin-ALIX mechanism was estimated to control around $50 \%$ of the secreted vesicles in MCF-7 cells [37], in agreement with the idea that different sorting mechanisms may operate in the sorting of exosomal molecules.

Some studies suggest that MVB biogenesis can occur without ESCRTs. For example, it has been shown that despite simultaneously silencing of key subunits of all four ESCRT-complexes, ILVs are still formed in MVBs, thus indicating the presence of ESCRT-independent mechanisms [38]. Tetraspanins, transmembrane proteins enriched in exosomes, are also involved in ESCRT-independent exosome release [39]. Expression of the tetraspanins CD9 and CD82 has been shown to enhance the exosomal release of $\beta$-catenin from HEK293 cells [40]. In the same study, the authors also showed that bone marrow dendritic cells (BMDCs) from CD9 knockout mice secrete less exosomeassociated flotillin-1. Another tetraspanin that has been shown to be involved in exosome biogenesis is Tspan8 [41]. Expression of Tspan8 in rat adenocarcinoma cells did not affect the total amount of secreted exosomes, but rather changed the mRNA and protein composition of exosomes. Recently, the tetraspanin CD63 was shown to play a role in exosome biogenesis as well [42]. CRISPR/Cas9 knockout of CD63 resulted in reduced secretion of EVs, measured 
by NTA [42]. The same authors have also shown that cells expressing the Epstein-Barr virus encoded latent membrane protein 1 (LMP1) secreted more exosomes compared to cells not expressing this protein, and that the LMP1induced particle secretion and packaging into exosomes required CD63 [43].

Another protein that has been suggested to play a role in exosome formation is the small integral membrane protein of the lysosome/late endosome (SIMPLE, also called lipopolysaccharide induced TNF factor, LITAF). Increased secretion of exosomes was observed after transfection of COS cells with SIMPLE, and mutation of SIMPLE interfered with proper MVB formation [44].

In addition to proteins, lipids are also essential players in vesicular transport [45], and both types of molecules collaborate closely in essential processes intrinsic to vesicular transport such as membrane deformation, fission and fusion [46]. Membrane curvature is strongly dependent on the shape of the individual membrane lipids, which depends on the size of the headgroup and on the length and saturation of the acyl chains. Several studies have shown the involvement of lipids in exosome formation by targeting specific lipid modifying enzymes. Inhibition of neutral sphingomyelinase 2 (nSMase2), an enzyme that generates ceramide from sphingomyelin, has been shown to reduce exosomal release of proteolipid protein (PLP) from Olineu cells [47]. The same study also showed that inhibition of nSMase2 reduced the release of exosomal EGFP-CD63 from EGFP-CD63-transfected PC-3 cells. The mechanism of this effect is not clear, but it may be due to the formation of ceramide microdomains that coalescence into larger domains that promote membrane budding [47]. It should be mentioned that the role of ceramide in exosome release is not a general one, because it has been reproduced in several [48, 49], but not all [50, 51] cell lines where it has been tested. In PC-3 cells, for example, exosomal release was neither affected by nSMase 2 inhibition nor inhibition of de novo synthesis of ceramide [50]. Other lipid modifying enzyme that has been studied in the context of exosome generation is phospholipase D2 (PLD2), an enzyme that produces phosphatidic acid (PA) from phospholipids. The activity of this enzyme was first associated with the release of exosomes in RBL-2H3 cells [52]. A few years later, PLD2 was shown to act as an effector of the small GTPase ADP ribosylation factor 6 (ARF6), which was identified as a regulator of ILV formation and exosome biogenesis [53]. PA, which similarly to ceramide has a small headgroup, may favor membrane invagination by inducing a negative membrane curvature [54], but the direct involvement of PA in the effect PLD2 on exosome biogenesis has not been demonstrated. Finally, diacylglycerol kinase $\alpha(D G K \alpha)$, an enzyme that adds a phosphate group to the lipid second messenger DAG and generates PA, has been shown to regulate the release of exosomes from $\mathrm{T}$ lymphocytes [55]. The activity of this kinase seems to play a negative role in the formation of mature MVBs, but also to affect the polarized traffic of MVBs [56]. Moreover, it has recently been shown that the effect of DGK $\alpha$ in the maturation of MVBs and exosome secretion is mediated by protein kinase $\mathrm{D} 1 / 2$ [57].

The biogenesis of exosomes has often been described as an ESCRT-dependent or ESCRT-independent mechanism [2], but the pathways might not be entirely separated [58]. The pathways might work synergistically, and different subpopulations of exosomes could depend on different machineries. Moreover, the cell type and/or cellular homeostasis could be an important factor in the machinery that controls the secretion of exosomes.

\section{Sorting of cargo into exosomes}

Exosomes contain different proteins, lipids and nucleic acids. Their composition is to some extent cell type dependent and can also be influenced by different cellular conditions or treatments. Moreover, exosomes released by a cell line are probably quite heterogeneous [28]. Several studies have described the protein, lipid and RNA cargo of exosomes, but less is known about whether and how the cargo is sorted into the vesicles. Certain miRNAs are enriched in exosomes relative to cells, indicating that miRNAs can be sorted into exosomes [49, 59-61]. Interestingly, a sequence motif that controls the loading of miRNAs through binding to the protein heterogeneous nuclear ribonucleoprotein A2B1 (hnRNPA2B1) has been identified [62]. Exosomal hnRNPA2B1 is sumoylated, and this modification seems to be essential for its miRNA binding [62]. Moreover, KRAS has been shown to play a role in miRNA sorting into exosomes. Exosomes from mutant KRAS colorectal cancer cells show a distinct miRNA profile compared to wild type cells [63]. Furthermore, inhibition of nSMase caused cellular accumulation of certain miRNAs in KRAS mutant, but not wild type cells. Another study has shown that overactive mutated KRAS inhibits localization of the RISC component Argonaute 2 (Ago2) to MVBs and decreases Ago2 secretion in exosomes [64]. Inhibition of mitogen-activated protein kinase kinases (MEKs) I and II was shown to reverse the effect of the activating KRAS mutation, leading to increased exosomal Ago2 secretion. mRNAs also seem to be selectively enriched in exosomes [65]. Exosomal mRNAs show enrichment in 3'UTR fragments [66], which could play a role for mRNA sorting into the vesicles [67]. Exosomes have also been shown to contain ubiquitinated proteins $[10,68]$, and ubiquitination could be a mechanism to target proteins to exosomes [69, 70]. 
Lipids may also be important for sorting of specific proteins into exosomes. Interestingly, exosomes have been shown to be enriched in cholesterol, sphingomyelin and glycosphingolipids compared to their parent cells [71, 72]. This suggests that exosomal membranes may contain lipid rafts, membrane subdomains enriched in cholesterol and glycosphingolipids that play important roles in signaling and sorting [73, 74]. In fact, one of the first studies on the role of lipids in exosome release showed that lyn, flotillin-1 and stomatin are released to the extracellular medium via their association with lipid domains (Triton X-100-insoluble fractions) in the exosomal membrane [75]. In addition, sphingosine 1-phosphate (SP1), a lipid formed by the phosphorylation of sphingosine by sphingosine kinase 1 (Sphk1) and 2 (Sphk2), has been shown to regulate cargo (such as CD63, CD81 and flotillin) sorting into exosomes via inhibitory $\mathrm{G}$ protein $(\mathrm{Gi})$-coupled $\mathrm{S} 1 \mathrm{P}$ receptors located on MVB membranes [76]. These receptors are continuously activated through a constant supply of S1P catalysed by sphingosine kinase (SphK), though it is not clear how the kinase is recruited to MVBs. Importantly, impairment of S1P signalling did not reduce the total number or size of exosomes, even if secreted exosomes contained lower amounts of CD63. This suggests that S1P signalling is mainly involved in sorting of cargo molecules into exosomes, and not in ILV formation [76].

\section{Transport of MVBs to the plasma membrane and exosome release}

Multivesicular bodies can either be directed to lysosomes where their content is degraded or transported to the plasma membrane for exosome release. Little is known about the molecular mechanisms and the cellular statues that regulate this balance. Recently, ISGylation, a posttranslational ubiquitin-like modification, was proposed to be one of the signals regulating the MVBs' fate [77]. Induction of ISGylation was shown to impair exosome secretion, measured by quantification of several exosomal markers by WB, as well as by NTA. The authors suggested that ISGylation of MVB proteins promotes fusion of MVBs with lysosomes, thereby directing MVBs to the degradation pathway and away from the secretory pathway [77].

Transport of MVBs to the plasma membrane is dependent on their interaction with actin and the microtubule cytoskeleton $[34,49,78]$. Knockdown or overexpression of the actin binding protein cortactin has been shown to decrease or increase exosome release, respectively [79]. Moreover, live-cell imaging indicated that cortactin is involved in both trafficking and docking of MVBs to the plasma membrane [79]. Rab GTPases, the largest family of small GTPases [80], regulate many steps of membrane trafficking, including vesicle budding, transport of vesicles along actin and tubulin, as well as membrane fusion. Interestingly, several Rab GTPases have been shown to play a role in exosome secretion, although their precise mechanism of action in this process is not known. The first Rab GTPase shown to be involved in exosome secretion was Rab11. Overexpression of a dominant-negative Rab11 mutant inhibited exosome release, measured by quantification of the exosomal levels of transferrin receptor, Lyn and HSC70, in human leukemic K562 cells [81]. In line with this, depletion of Rab11 in Drosophila S2 cells reduced the release of Evibearing exosomes [82]. On the contrary, Rab11 was not found to affect exosome release from HeLa cells [83]. Hsu et al. showed that knockdown of Rab35 decreased the release of exosome-associated proteolipid protein (PLP) from the oligodendroglial cell line Oli-neu, possibly due to reduced docking/tethering of MVBs at the plasma membrane [84]. Reduced exosome release after Rab35 knockdown was later confirmed by Fruhbeis et al. using the same model [85], whereas Rab35 depletion did not affect exosome release from Drosophila S2 cells [82].

In a shRNA screening targeting 59 Rab GTPases in HeLa cells, five of them were found to be involved in exosome secretion [83]. After shRNA transfection, secreted exosomes were trapped on anti-CD63-beads and detected by anti-CD81 and anti-HLA-DR (MHC II) antibodies using FC. Knockdown of Rab2b, Rab5a, Rab9a, Rab27a and Rab27b decreased exosome secretion in the screening assay. The effect of Rab27a and Rab27b was verified by measuring the total amount of exosomal protein, as well as the exosomal level of HLA-DR, HSC70 and TSG101. Ostrowski et al. also showed by total internal reflection fluorescence (TIRF) microscopy that Rab27a and Rab27b depletion reduced docking of MVBs to the plasma membrane [83]. The effect of Rab27a on exosome release has been reported in several studies using different cell lines $[14,34,86,87]$. Nevertheless, some studies do not show an effect of Rab27 knockdown on exosome release [82, 88]. The last Rab protein that has been shown to be involved in exosome secretion is Rab7. Baietti et al. showed that Rab7 regulates secretion of syntenin and syndecan-containing exosomes from MCF-7 cells, whereas no effect was observed in HeLa cells [35, 83]. Moreover, Rab7 and Rab27b, but not Rab27a, have been shown to regulate secretion of exosomal miR-143 from HUVEC cells [89]. Contrary to previous studies, a recent report showed that knockdown of Rab27b increased particle release from PC-3 cells [90]. However, in this study exosomes were not isolated and the conditioned media was measured by NTA directly after $12,000 \times g$ centrifugation. The discrepant findings might be due to cell-specific regulations, or due to methodological challenges, such as different protocols for 
isolation of vesicles and different methods to quantify the amount of released exosomes (discussed below).

Small GTPases of other families such as the Rho/Rac/ cdc42 family might also play a role in exosome release. In particular, in a study of RhoGTPases in HIV-1 virion production, the RhoA effector citron kinase was shown to increase the release of exosomes [91].

Exosomes are released into the extracellular environment upon fusion of MVBs with the plasma membrane. During this process several energy barriers need to be overcome. A number of protein-lipid and protein-protein interactions have been shown to reduce these energy barriers and facilitate fusion, as well as to provide specificity. Proteins involved in membrane fusion include soluble $N$-ethylmaleimide-sensitive factor attachment protein receptors (SNAREs), tethering factors, Rabs, and other Ras GTPases [92]. The specific molecular machinery for fusion of MVBs with the plasma membrane is not well characterized.

SNARE proteins facilitate fusion of vesicles with their target membrane, such as the plasma membrane or the membrane of different organelles [93]. A SNARE complex is built up by three or four SNARE proteins forming four coiled-coil helices. The members of this protein family are classified as either R- or Q-SNAREs. Generally, fusion involves one R-SNARE (usually v-SNARE) and three Q-SNAREs (usually t-SNAREs) [92]. Fader et al. showed that the R-SNARE vesicle-associated membrane protein 7 (VAMP7) is necessary for exosome release in the human leukemic cell line K562 [94]. In this paper, overexpression of the N-terminal domain of VAMP7, which inhibits SNARE complex formation, reduced exosome release, measured as exosome-associated acetylcholinesterase. The authors also observed that the MVBs were enlarged and distributed to the cell periphery after overexpression of the $\mathrm{N}$-terminal domain of VAMP7, thus suggesting that the fusion of MVBs with the plasma membrane was impaired [94].

Another R-SNARE protein, YKT6, has been shown to be required for exosome release in two independent studies. Gross et al. showed that depletion of YKT6 decreased the level of TSG101, WNT3A and VPS26/35 in exosomes secreted from human embryonic kidney HEK293 cells [33]. In line with this, Ruiz-Martinez et al. showed a reduced level of exosome-associated TSG101 after knockdown of YKT6 in A549 human lung cancer cells [95]. In Drosophila S2 cells, depletion of the Q-SNARE syntaxin 1A (Syx1A) decreased release of Evi-bearing exosomes [82]. Recently, pyruvate kinase type M2 (PKM2) was shown to phosphorylate SNAP-23, which in turn enables exosome release [96].

A study in Caenorhabditis elegans indicated that the Ras-related GTPase homolog (Ral-1) is involved in MVB formation and fusion with the plasma membrane [97].
Likewise, in 4T1 mouse mammary tumor cells, knockdown of the mammalian homologs Ras like proto-oncogene A (RalA) and RalB reduced the secretion of exosome-like vesicles. In that study exosome release was quantified by electron microscopy (EM) and by the exosomal level of ALIX, CD63, HSC70 and TSG101 [97]. Interestingly, the authors also showed that MVBs accumulate under the plasma membrane when the Q-SNARE syntaxin 5 was absent in C. elegans.

Furthermore, addition of an ether lipid precursor that increases the levels of cellular (and exosomal) ether lipids has been shown to increase the release of exosomes from PC-3 cells [98]. The mechanism of this effect is not clear, but ether lipids have previously been suggested to be involved in membrane fusion [99], and the increased exosome secretion could be due to facilitated fusion of MVBs with the plasma membrane. Moreover, addition of cholesterol (in complex with methyl-beta cyclodextrin) in Oli-neu cells has been shown to increase the exosomal levels of several proteins such as flotillin-2, ALIX and CD63 [100]. In contrast, a reduction of cholesterol levels in PC-3 cells, both by addition of methyl-beta cyclodextrin and by metabolic inhibition of its formation, increased the secretion of several exosomal proteins [101].

Importantly, it has been shown that exosome release can be regulated by calcium. Increased intracellular calcium level after treatment of human erythroleukemia K562 cells with monensin or the calcium ionophore A23187 has been shown to increase exosome secretion [102]. In line with this, the calcium ionophore ionomycin was shown to facilitate exosomal release of PLP from oligodendrocytes [103]. Some proteins, such as synaptotagmins, function as calcium sensors and have been implicated in vesicular transport [104]. Interestingly, a member of the synaptotagmin family has been reported to affect exosome release. Knockdown of synaptotagmin-7 was shown to reduce exosome secretion, as measured by NTA [34], likely by affecting the fusion of the MVBs with the plasma membrane.

Interestingly, it has been shown that inactivation of the vacuolar ATPase (V-ATPase) in HeLa cells results in increased exosome secretion, and that the exosomes remain clustered and attached to the plasma membrane by tetherin [105]. This indicates that these exosomes may not reach long distances and may stay closely attached to the secreting cell. Regulation of tetherin expression could be a cellular mechanism to regulate whether exosomes should exert their effect locally or at longer distances.

\section{Cellular homeostasis affects exosome release}

It has been suggested that the destination of MVBs to either degradation or secretion depends on cellular homeostasis 
and that exosomes play a role in protecting cells against intracellular stress $[9,106]$. Several studies have shown that cellular stress increases exosome secretion [107-111]. Irradiation of cells has been shown to induce senescence and to increase exosome release $[107,108]$. Increased exosome release has also been reported after cisplatin treatment [109], as well as after exposure to hypoxia [110]. Furthermore, induction of ER stress by tunicamycin increased the number of cellular MVBs and enhanced exosome secretion [111]. It is not clear why cells respond to stress by releasing more exosomes, but this could be an alternative way of eliminating waste products. The secreted exosomes might be targeted to and degraded by phagocytes, but they might also have other destinations. Exosomes secreted as waste are likely to affect neighboring cells and possibly induce pathological conditions. Another possibility is that cells might communicate to neighboring cells about intracellular stress by increasing exosome release.

Similarly to the stress hypothesis, a link between autophagy and exosomes has been proposed [9]. Autophagy is a degradative pathway that supplies nutrients during starvation and eliminates damaged organelles, aggregated proteins and invading pathogens [112]. This pathway can be induced by various stimuli to maintain cellular homeostasis. Upon autophagy induction cytoplasmic cargo is trapped within double-membrane vesicles termed autophagosomes, which can fuse with MVBs to form amphisomes or directly with lysosomes [112]. The cargo is then degraded in the lysosomes and the components are transported back to the cytoplasm. Fader et al. showed that induction of autophagy by starvation reduced exosome release [113]. The authors proposed that this was caused by increased fusion of MVBs with autophagosomes, thereby directing MVBs to the degradative pathway. Moreover, inhibition of autophagy by ATG7 depletion has been shown to enhance exosomal secretion of GAPDH [114]. Recently, we showed that inhibition of the phosphoinositide kinase PIKfyve, which generates phosphatidylinositol-3,5-bisphosphate, increased exosome release and reduced autophagic degradation, most likely due to a reduced fusion of lysosomes with both MVBs and autophagosomes [10]. Rather than an effect of autophagy per se on exosome release, this could be due to interference with transport or fusion of the organelles. In line with this, it has also been shown that lysosomal dysfunction induced by ammonium chloride or bafilomycin A1 leads to increased secretion of alpha-synuclein in exosomes from SH-SY5Y cells [115]. In such cases where the transport through the degradative pathway is obstructed or the lysosomal pathway is overloaded due to stress, exosome release might indeed be an alternative route to dispose waste.

Murrow et al. showed that basal autophagy is impaired in cells lacking ATG12-ATG3, a conjugate of two autophagy-related proteins, whereas starvation-induced autophagy is not affected [116]. The authors also showed that ATG12-ATG3 deficiency impaired exosome release, measured as total exosomal protein as well as by the levels of several exosomal markers, and suggested this was due to impaired late endosomal function. This could be another mechanism linking exosomes to autophagy.

In addition to its more thoroughly studied role in degradation, the autophagic machinery is also involved in a less known process termed secretory autophagy [117]. Secretory autophagy is considered as an unconventional secretion process that releases numerous cytoplasmic substrates from the cell [117]. Since secretory autophagy is induced in cells with lysosomal dysfunction this might be, in a similar way as exosomes, an alternative way of eliminating waste products. Certain neurodegenerative diseases are associated with dysfunctional autophagy and deposition of aggregation-prone proteins, thus secretory autophagy might play a role in these diseases $[118,119]$.

Furthermore, not only MVBs, amphisomes and autophagosomes can release their content to the extracellular environment, but also lysosomes in a process called lysosomal exocytosis [120]. These secretion pathways indeed share some features and do somewhat overlap. When a cell is no longer able to degrade material in the lysosomes due to a lysosomal defect, lysosomal overload or transport interference, secretion of the content of lysosomes, MVBs or amphisomes could be a way to rescue the cell. Furthermore, when amphisomes fuse with the plasma membrane, the ILVs included in the amphisome will appear extracellularly as exosomes. Also if a lysosome secretes its content before it is fully degraded, remaining ILVs can be released as exosomes. Though these pathways cannot be entirely separated, each pathway is probably regulated by distinct machineries.

\section{Methodological aspects related to studies of exosome release}

There is no consensus in the literature about the optimal methods and conditions to study exosome biogenesis and release. The methodology is continuously being developed as new technological advances appear and new knowledge is generated. In this section, we describe the different parameters that have to be considered and the different methods that are used to study exosome release. Importantly, different methodological approaches might explain reproducibility issues. It should be mentioned that this section is not meant to give an overview of the exosome methodology in general (for reviews on the subject see [121-126]), but to present methodological aspects related to exosome biogenesis and release studies. 


\section{Cellular models}

Studies of exosome biogenesis and release have mainly been performed using in vitro grown cell lines as a model. There are few published comparative studies [127], but different cell lines can be expected to release different levels of exosomes to the extracellular environment. It should also be mentioned that some cell lines may have cell-specific molecular machineries for exosome biogenesis and release. Therefore, in order to generalize the function of a specific molecule in exosome release, several cell lines and readouts of exosome release have to be tested.

\section{Exosome collection}

The amount of exosomes needed in each experiment depends on the sensitivity of the quantification method. Based on this and on the cell line that is going to be used, the number of cells per experiment and/or the collection time of exosomes can be adjusted. Kinetic studies of exosome release are not often seen in the literature. Authors often choose a specific collection time that varies from a few hours to several days. We have observed that there is an increasing release of exosomes during the first $24 \mathrm{~h}$ in PC-3 cells [101]. The medium in which the exosomes are collected is also an important factor. Many cell lines are grown in the presence of fetal calf serum, which naturally contains exosomes, and thus may affect the results. To avoid this problem, exosomes are either collected in medium without serum, if the cells tolerate this, or with medium depleted of exosomes [122]. It should be mentioned that other medium supplements, such as bovine pituitary extract, even though they might not contain exosomes, might contain other vesicles or proteins that may be pelleted with exosomes during ultracentrifugation.

\section{Exosome isolation}

Exosomes have often been isolated by sequential centrifugation in exosome release studies. This method includes 2-3 centrifugations at low speeds to remove cells, cell debris and microvesicles, followed by ultracentrifugation at approximately $100,000 \times g$ for $1-2 \mathrm{~h}$ and a PBS wash [122]. It cannot be expected that this method gives a pure exosome population because the size of exosomes and microvesicles overlaps to some extent, but a fraction that is enriched in exosomes. Importantly, it has recently been shown that the $100,000 \times g$ pellet could be divided into several categories both by floatation into iodixanol gradients and by immunoisolation using beads coated with antibodies targeting either CD9, CD63, or CD81 [28]. Based on these results it was suggested that vesicles in the $100,000 \times g$ pellet should be referred to as "small EVs" (sEVs) instead of exosomes
[28]. Moreover, if present, lipoparticles from serum and lipid droplets would be co-isolated together with exosomes during ultracentrifugation [71]. Autophagosomes can contain lipid droplets in their lumen that would be released from the cells and co-isolated with exosomes if secretory autophagy is induced [10]. As recently discussed in another review, the presence of large amounts of triacylglycerol or cholesteryl ester in exosome preparations is an indication of contamination with lipid droplets or lipoproteins [71]. The heterogeneity of the $100,000 \times g$ pellet and the presence of potential contaminations are likely to have caused some of the discrepancies reported in exosome release studies. Another drawback of ultracentrifugation is that the throughput is limited by the rotor capacity.

Although differential centrifugation is the most common method used for exosome isolation, other methods can be used to obtain exosome or exosome-enriched samples. Density gradient centrifugation was shown to give the purest exosome population when compared to ultracentrifugation and precipitation-based methods [121]. However, this method gives a relatively low yield and is time consuming. Moreover, Kowal et al. reported that density gradient centrifugation of $100,000 \times g$ pellets was not able to clearly separate subpopulations of small EVs [28]. Immunoisolation of exosomes based on specific proteins at the exosomal membrane is also a method that would result in relatively pure EV subpopulations [28, 128], but it requires that the selected membrane protein is carefully chosen and that the immunoisolation protocol is optimized. Interestingly, Tauro et al. reported that immunoaffinity capture was more efficient to isolate exosomes from a colon cancer cell line than ultracentrifugation and density gradient isolation [129]. Surface plasmon resonance (SPR) also allows analyzing specific exosome populations. SPR-based quantification of exosomes is based on the capture of exosomes on an immuno-functionalized surface and measurements of the resulting change in refractive index. This methodology has shown promising results in detecting exosomes containing specific exosomal markers such as CD63 as well as cancer specific proteins [130-132]. Another isolation technique is based on the precipitation of exosomes with volume-excluding polymers such as polyethylene glycol (PEG). This is a rapid method, but that probably results in the coisolation of exosomes with other structures of similar sizes. Finally, a method that is gaining popularity in the EV field is size exclusion chromatography (SEC). This method allows the separation of exosomes from proteins, but not from microvesicles, protein aggregates and lipoparticles.

Whether it is beneficial to isolate specific exosome subpopulations rather than all small vesicles remains a question for debate. At the present stage, there is little knowledge about the function of the different EV subpopulations. The EV subpopulations, and their protein markers, might 
also be highly dependent on the cell type, as well as the homeostasis and treatment of the cell. Thus, one should be careful to apply strict guidelines for categorizing EV subpopulations at this point. The optimal isolation method will depend on the aim of the study, the downstream analysis and which impurities are acceptable in that context. Importantly, it seems clear that the choice of isolation method can affect the results obtained from studies on exosome biogenesis and release.

\section{Exosome analysis}

To investigate whether a specific treatment or molecule affects exosome release, the number of vesicles released has to be determined (Fig. 1). In many cases, this has been measured in an indirect manner for example by measuring the enzymatic activity of a specific exosomal protein or the levels of typical exosomal proteins such as TSG101 or ALIX, or specific proteins (PLP) (Table 1). These methods should be supplemented with additional methods and/ or additional molecules since alterations in the cellular levels or sorting of the chosen protein by the treatment might affect the results. Moreover, Kowal et al. have shown that the $100,000 \times g$ pellet contains subpopulations of vesicles with different protein composition [28]. In addition, the authors found that some of the proteins commonly used as exosomal markers are also present on bigger vesicles recovered in the $2000 \times g$ and the $10,000 \times g$ pellets. Based on their results, the authors concluded that syntenin- 1 and TSG101 can be considered specific markers of bona fide exosomes. It is likely that the analysis of only one or a few proteins, some of which have retrospectively not been shown to be optimal exosomal markers, in studies of exosome release might have affected the conclusions drawn. Mass spectrometry studies appear as a good alternative since they allow a more general characterization of the exosome proteome.

A more general, but still indirect method to analyze exosome release is to measure the total amount of protein (total amount of lipid or RNA can also be measured) in exosomes. However, this requires that the treatment does not change the vesicle size or content. In addition, the method requires that the exosome samples are not contaminated by protein aggregates. Methods that combine measurement of the total protein and lipid content of exosomes have also been tested [133]. FC after capture on beads has been used in several studies $[83,134]$, and direct FC has also become an option using specific methods or instruments with small particle detection capability [135]. Recently, NTA and tunable resistive pulse sensing (TRPS) have emerged as new methods to measure exosome concentration [136-138] and have been used in exosome release studies $[10,139]$. These can be considered as direct methods since they measure the concentration of particles in solution. However, one should be aware that they do not exclusively measure exosomes, and that particles of similar sizes in the samples such as aggregates or virus will be counted. Another technique that allows quantification of exosomes is SPR, as mentioned above. In conclusion, several methods are available to directly or indirectly measure the number of exosomes released, and a combination of several methods is recommended to confirm the implication of a molecule in the process. However, exosome release is the result of several steps, and quantifying the released exosomes does not indicate which step is affected. More insight can be obtained by studying MVB morphology, number, location and ability to fuse with the plasma membrane. A few studies have addressed this issue by using immunofluorescence microscopy [83] or electron microscopy $[10,84,98]$, but further methodological developments are required to study the different steps independently.

\section{Conclusion}

Several molecules have been implicated in exosome biogenesis and release, but for many of them, the exact mechanism of action is not clear yet. Exosome biogenesis and secretion seem to utilize several machineries, depending on either cell type or cellular homeostasis. In addition, different MVB subtypes might exploit different pathways. Finding consensus in the field is complicated by methodological challenges such as the use of different methods for exosome isolation and quantification. However, this is an interesting field that needs to be further explored. Moreover, considering the role of exosomes in physiological and pathological conditions, strategies that interfere with the release of exosomes and impair exosome-mediated cell-to-cell communication could potentially be exploited therapeutically in the future.

Acknowledgements We would like to thank Kirsten Sandvig for carefully reading the manuscript and giving insightful comments. This work was supported by The Norwegian Cancer Society, The Research Council of Norway through its Centers of Excellence funding scheme, Project Number 179571, and The Norwegian Financial Mechanism 2009-2014 under Project Contract Number NFI/R/2014/045.

\section{Compliance with ethical standards}

Conflict of interest The authors declare that they have no conflict of interest.

Open Access This article is distributed under the terms of the Creative Commons Attribution 4.0 International License (http:// creativecommons.org/licenses/by/4.0/), which permits unrestricted use, distribution, and reproduction in any medium, provided you give appropriate credit to the original author(s) and the source, provide a link to the Creative Commons license, and indicate if changes were made. 


\section{References}

1. Wolf $P$ (1967) The nature and significance of platelet products in human plasma. Br J Haematol 13(3):269-288

2. Raposo G, Stoorvogel W (2013) Extracellular vesicles: exosomes, microvesicles, and friends. J Cell Biol 200(4):373383. doi: $10.1083 /$ jcb. 201211138

3. Yanez-Mo M, Siljander PR, Andreu Z, Zavec AB, Borras FE, Buzas EI, Buzas K, Casal E, Cappello F, Carvalho J, Colas E, Cordeiro-da Silva A, Fais S, Falcon-Perez JM, Ghobrial IM, Giebel B, Gimona M, Graner M, Gursel I, Gursel M, Heegaard NH, Hendrix A, Kierulf P, Kokubun K, Kosanovic M, KraljIglic V, Kramer-Albers EM, Laitinen S, Lasser C, Lener T, Ligeti E, Line A, Lipps G, Llorente A, Lotvall J, Mancek-Keber M, Marcilla A, Mittelbrunn M, Nazarenko I, Nolte-'t Hoen EN, Nyman TA, O'Driscoll L, Olivan M, Oliveira C, Pallinger E, Del Portillo HA, Reventos J, Rigau M, Rohde E, Sammar M, Sanchez-Madrid F, Santarem N, Schallmoser K, Ostenfeld MS, Stoorvogel W, Stukelj R, Van der Grein SG, Vasconcelos MH, Wauben MH, De Wever O (2015) Biological properties of extracellular vesicles and their physiological functions. J Extracell Vesicles 4:27066. doi:10.3402/jev.v4.27066

4. Harding C, Heuser J, Stahl P (1983) Receptor-mediated endocytosis of transferrin and recycling of the transferrin receptor in rat reticulocytes. J Cell Biol 97(2):329-339

5. Pan BT, Teng K, Wu C, Adam M, Johnstone RM (1985) Electron microscopic evidence for externalization of the transferrin receptor in vesicular form in sheep reticulocytes. J Cell Biol 101(3):942-948. doi:10.1083/jcb.101.3.942

6. Johnstone RM (2005) Revisiting the road to the discovery of exosomes. Blood Cells Mol Dis 34(3):214-219. doi:10.1016/j. bcmd.2005.03.002

7. Johnstone RM, Adam M, Hammond JR, Orr L, Turbide C (1987) Vesicle formation during reticulocyte maturation. Association of plasma membrane activities with released vesicles (exosomes). J Biol Chem 262(19):9412-9420

8. Colombo M, Raposo G, Thery C (2014) Biogenesis, secretion, and intercellular interactions of exosomes and other extracellular vesicles. Annu Rev Cell Dev Biol 30:255-289. doi:10.1146/ annurev-cellbio-101512-122326

9. Baixauli F, Lopez-Otin C, Mittelbrunn M (2014) Exosomes and autophagy: coordinated mechanisms for the maintenance of cellular fitness. Front Immunol 5:403. doi:10.3389/ fimmu.2014.00403

10. Hessvik NP, Overbye A, Brech A, Torgersen ML, Jakobsen IS, Sandvig K, Llorente A (2016) PIKfyve inhibition increases exosome release and induces secretory autophagy. Cell Mol Life Sci 73(24):4717-4737. doi:10.1007/s00018-016-2309-8

11. Mathivanan S, Ji H, Simpson RJ (2010) Exosomes: extracellular organelles important in intercellular communication. J Proteom 73(10):1907-1920

12. Record M, Carayon K, Poirot M, Silvente-Poirot S (2014) Exosomes as new vesicular lipid transporters involved in cell-cell communication and various pathophysiologies. Biochim Biophys Acta 1841(1):108-120. doi:10.1016/j. bbalip.2013.10.004

13. Becker A, Thakur BK, Weiss JM, Kim HS, Peinado H, Lyden D (2016) Extracellular vesicles in cancer: cell-to-cell mediators of metastasis. Cancer Cell 30(6):836-848. doi:10.1016/j. ccell.2016.10.009

14. Peinado H, Aleckovic M, Lavotshkin S, Matei I, Costa Silva B, Moreno Bueno G, Hergueta Redondo M, Williams C, GarciaSantos G, Ghajar C, Nitadori Hoshino A, Hoffman C, Badal K, Garcia B, Callahan M, Yuan J, Martins V, Skog J, Kaplan R,
Brady M, Wolchok J, Chapman P, Kang Y, Bromberg J, Lyden D (2012) Melanoma exosomes educate bone marrow progenitor cells toward a pro-metastatic phenotype through MET. Nat Med 18(6):883-891

15. Costa-Silva B, Aiello NM, Ocean AJ, Singh S, Zhang H, Thakur BK, Becker A, Hoshino A, Mark MT, Molina H, Xiang J, Zhang T, Theilen TM, Garcia-Santos G, Williams C, Ararso Y, Huang Y, Rodrigues G, Shen TL, Labori KJ, Lothe IM, Kure EH, Hernandez J, Doussot A, Ebbesen SH, Grandgenett PM, Hollingsworth MA, Jain M, Mallya K, Batra SK, Jarnagin WR, Schwartz RE, Matei I, Peinado H, Stanger BZ, Bromberg J, Lyden D (2015) Pancreatic cancer exosomes initiate pre-metastatic niche formation in the liver. Nat Cell Biol 17(6):816-826. doi: $10.1038 /$ ncb3169

16. Hoshino A, Costa-Silva B, Shen TL, Rodrigues G, Hashimoto A, Tesic Mark M, Molina H, Kohsaka S, Di Giannatale A, Ceder S, Singh S, Williams C, Soplop N, Uryu K, Pharmer L, King T, Bojmar L, Davies AE, Ararso Y, Zhang T, Zhang H, Hernandez J, Weiss JM, Dumont-Cole VD, Kramer K, Wexler LH, Narendran A, Schwartz GK, Healey JH, Sandstrom P, Labori KJ, Kure EH, Grandgenett PM, Hollingsworth MA, de Sousa M, Kaur S, Jain M, Mallya K, Batra SK, Jarnagin WR, Brady MS, Fodstad O, Muller V, Pantel K, Minn AJ, Bissell MJ, Garcia BA, Kang Y, Rajasekhar VK, Ghajar CM, Matei I, Peinado H, Bromberg J, Lyden D (2015) Tumour exosome integrins determine organotropic metastasis. Nature 527(7578):329-335. doi:10.1038/nature15756

17. Mobius W, Ohno-Iwashita Y, van Donselaar EG, Oorschot VM, Shimada Y, Fujimoto T, Heijnen HF, Geuze HJ, Slot JW (2002) Immunoelectron microscopic localization of cholesterol using biotinylated and non-cytolytic perfringolysin $\mathrm{O}$. J Histochem Cytochem 50(1):43-55

18. White IJ, Bailey LM, Aghakhani MR, Moss SE, Futter CE (2006) EGF stimulates annexin 1-dependent inward vesiculation in a multivesicular endosome subpopulation. EMBO J 25(1):1-12. doi:10.1038/sj.emboj.7600759

19. Kobayashi T, Startchev K, Whitney AJ, Gruenber J (2001) Localization of lysobisphosphatidic acid-rich membrane domains in late endosomes. Biol Chem 382(3):483-485. doi: $10.1515 / \mathrm{bc} .2001 .059$

20. Chen Q, Takada R, Noda C, Kobayashi S, Takada S (2016) Different populations of Wnt-containing vesicles are individually released from polarized epithelial cells. Sci Rep 6:35562. doi:10.1038/srep35562

21. van Niel G, Raposo G, Candalh C, Boussac M, Hershberg R, Cerf-Bensussan N, Heyman M (2001) Intestinal epithelial cells secrete exosome-like vesicles. Gastroenterology 121(2):337-349

22. Tauro BJ, Greening DW, Mathias RA, Mathivanan S, Ji H, Simpson RJ (2013) Two distinct populations of exosomes are released from LIM1863 colon carcinoma cell-derived organoids. Mol Cell Proteom 12(3):587-598. doi:10.1074/mcp. M112.021303

23. Pocsfalvi G, Stanly C, Vilasi A, Fiume I, Capasso G, Turiak L, Buzas EI, Vekey K (2016) Mass spectrometry of extracellular vesicles. Mass Spectrom Rev 35(1):3-21. doi:10.1002/ mas. 21457

24. Llorente A, Skotland T, Sylvanne T, Kauhanen D, Rog T, Orlowski A, Vattulainen I, Ekroos K, Sandvig K (2013) Molecular lipidomics of exosomes released by PC-3 prostate cancer cells. Biochim Biophys Acta 1831(7):1302-1309

25. Greening DW, Xu R, Gopal SK, Rai A, Simpson RJ (2017) Proteomic insights into extracellular vesicle biology - defining exosomes and shed microvesicles. Expert Rev Proteom 14(1):69-95. doi:10.1080/14789450.2017.1260450 
26. Kalra H, Simpson R, Ji H, Aikawa E, Altevogt P, Askenase $\mathrm{P}$, Bond V, Borras FE, Breakefield X, Budnik V, Buzas E, Camussi G, Clayton A, Cocucci E, Falcon Perez J, Gabrielsson S, Gho Y, Gupta D, Harsha HC, Hendrix A, Hill A, Inal J, Jenster G, Krämer-Albers E-M, Lim S, Llorente A, Lötvall J, Marcilla A, Mincheva Nilsson L, Nazarenko I, Nieuwland R, Nolte-'t Hoen ENM, Pandey A, Patel T, Piper M, Pluchino S, Prasad TSK, Rajendran L, Raposo G, Record M, Reid G, Sanchez-Madrid F, Schiffelers R, Siljander P, Stensballe A, Stoorvogel W, Taylor D, Thery C, Valadi H, van Balkom BWM, Vazquez J, Vidal M, Wauben MHM, Yanez-Mo M, Zoeller M, Mathivanan S (2012) Vesiclepedia: a compendium for extracellular vesicles with continuous community annotation. PLoS Biol 10(12):e1001450-e1001450

27. Kim DK, Kang B, Kim OY, Choi DS, Lee J, Kim SR, Go G, Yoon YJ, Kim JH, Jang SC, Park KS, Choi EJ, Kim KP, Desiderio DM, Kim YK, Lotvall J, Hwang D, Gho YS (2013) EVpedia: an integrated database of high-throughput data for systemic analyses of extracellular vesicles. J Extracell Vesicles. doi: $10.3402 /$ jev.v2i0.20384

28. Kowal J, Arras G, Colombo M, Jouve M, Morath JP, Primdal-Bengtson B, Dingli F, Loew D, Tkach M, Thery C (2016) Proteomic comparison defines novel markers to characterize heterogeneous populations of extracellular vesicle subtypes. Proc Natl Acad Sci USA 113(8):E968-E977. doi:10.1073/ pnas. 1521230113

29. Huotari J, Helenius A (2011) Endosome maturation. EMBO J 30(17):3481-3500. doi:10.1038/emboj.2011.286

30. Henne WM, Stenmark H, Emr SD (2013) Molecular mechanisms of the membrane sculpting ESCRT pathway. Cold Spring Harb Perspect Biol 5(9):a016766. doi:10.1101/cshperspect.a016766

31. Colombo M, Moita C, van Niel G, Kowal J, Vigneron J, Benaroch P, Manel N, Moita LF, Thery C, Raposo G (2013) Analysis of ESCRT functions in exosome biogenesis, composition and secretion highlights the heterogeneity of extracellular vesicles. J Cell Sci 126(Pt 24):5553-5565. doi:10.1242/jcs.128868

32. Tamai K, Tanaka N, Nakano T, Kakazu E, Kondo Y, Inoue J, Shiina M, Fukushima K, Hoshino T, Sano K, Ueno Y, Shimosegawa T, Sugamura K (2010) Exosome secretion of dendritic cells is regulated by Hrs, an ESCRT-0 protein. Biochem Biophys Res Commun 399(3):384-390. doi:10.1016/j. bbrc. 2010.07 .083

33. Gross JC, Chaudhary V, Bartscherer K, Boutros M (2012) Active Wnt proteins are secreted on exosomes. Nat Cell Biol 14(10):1036-1045. doi:10.1038/ncb2574

34. Hoshino D, Kirkbride KC, Costello K, Clark ES, Sinha S, Grega-Larson N, Tyska MJ, Weaver AM (2013) Exosome secretion is enhanced by invadopodia and drives invasive behavior. Cell Rep 5(5):1159-1168. doi:10.1016/j.celrep.2013.10.050

35. Baietti MF, Zhang Z, Mortier E, Melchior A, Degeest G, Geeraerts A, Ivarsson Y, Depoortere F, Coomans C, Vermeiren E, Zimmermann P, David G (2012) Syndecan-syntenin-ALIX regulates the biogenesis of exosomes. Nat Cell Biol 14(7):677685. doi:10.1038/ncb2502

36. Roucourt B, Meeussen S, Bao J, Zimmermann P, David G (2015) Heparanase activates the syndecan-syntenin-ALIX exosome pathway. Cell Res 25(4):412-428. doi:10.1038/cr.2015.29

37. Friand V, David G, Zimmermann P (2015) Syntenin and syndecan in the biogenesis of exosomes. Biol Cell 107(10):331-341. doi:10.1111/boc.201500010

38. Stuffers S, Sem Wegner C, Stenmark H, Brech A (2009) Multivesicular endosome biogenesis in the absence of ESCRTs. Traffic 10(7):925-937. doi:10.1111/j.1600-0854.2009.00920.x

39. Escola JM, Kleijmeer MJ, Stoorvogel W, Griffith JM, Yoshie O, Geuze HJ (1998) Selective enrichment of tetraspan proteins on the internal vesicles of multivesicular endosomes and on exosomes secreted by human B-lymphocytes. J Biol Chem 273(32):20121-20127

40. Chairoungdua A, Smith DL, Pochard P, Hull M, Caplan MJ (2010) Exosome release of beta-catenin: a novel mechanism that antagonizes Wnt signaling. J Cell Biol 190(6):1079-1091. doi:10.1083/jcb.201002049

41. Nazarenko I, Rana S, Baumann A, McAlear J, Hellwig A, Trendelenburg M, Lochnit G, Preissner KT, Zoller M (2010) Cell surface tetraspanin Tspan8 contributes to molecular pathways of exosome-induced endothelial cell activation. Cancer Res 70(4):1668-1678. doi:10.1158/0008-5472.can-09-2470

42. Hurwitz SN, Conlon MM, Rider MA, Brownstein NC, Meckes DG Jr (2016) Nanoparticle analysis sheds budding insights into genetic drivers of extracellular vesicle biogenesis. J Extracell Vesicles 5:31295. doi:10.3402/jev.v5.31295

43. Hurwitz SN, Nkosi D, Conlon MM, York SB, Liu X, Tremblay DC, Meckes DG Jr (2017) CD63 regulates Epstein-Barr virus LMP1 exosomal packaging, enhancement of vesicle production, and noncanonical NF-kappaB signaling. J Virol 91(5):e0113816. doi:10.1128/jvi.02251-16

44. Zhu H, Guariglia S, Yu RY, Li W, Brancho D, Peinado H, Lyden D, Salzer J, Bennett C, Chow CW (2013) Mutation of SIMPLE in Charcot-Marie-Tooth 1C alters production of exosomes. Mol Biol Cell 24 (11):1619-1637, S1611-S1613. doi:10.1091/mbc.E12-07-0544

45. Brugger B, Bankaitis VA (2012) Lipids and vesicular transport. Biochim Biophys Acta 1821(8):1039. doi:10.1016/j. bbalip.2012.05.005

46. McMahon HT, Boucrot E (2015) Membrane curvature at a glance. J Cell Sci 128(6):1065-1070. doi:10.1242/jcs.114454

47. Trajkovic K, Hsu C, Chiantia S, Rajendran L, Wenzel D, Wieland F, Schwille P, Brugger B, Simons M (2008) Ceramide triggers budding of exosome vesicles into multivesicular endosomes. Science 319(5867):1244-1247. doi:10.1126/ science. 1153124

48. Kosaka N, Iguchi H, Yoshioka Y, Takeshita F, Matsuki Y, Ochiya T (2010) Secretory mechanisms and intercellular transfer of microRNAs in living cells. J Biol Chem 285(23):1744217452. doi:10.1074/jbc.M110.107821

49. Mittelbrunn M, Gutierrez-Vazquez C, Villarroya-Beltri C, Gonzalez S, Sanchez-Cabo F, Gonzalez MA, Bernad A, SanchezMadrid F (2011) Unidirectional transfer of microRNA-loaded exosomes from $\mathrm{T}$ cells to antigen-presenting cells. Nat Commun 2:282

50. Phuyal S, Hessvik NP, Skotland T, Sandvig K, Llorente A (2014) Regulation of exosome release by glycosphingolipids and flotillins. FEBS J 281(9):2214-2227. doi:10.1111/febs.12775

51. van Niel G, Charrin S, Simoes S, Romao M, Rochin L, Saftig P, Marks MS, Rubinstein E, Raposo G (2011) The tetraspanin CD63 regulates ESCRT-independent and -dependent endosomal sorting during melanogenesis. Dev Cell 21(4):708-721. doi:10.1016/j.devcel.2011.08.019

52. Laulagnier K, Grand D, Dujardin A, Hamdi S, Vincent-Schneider H, Lankar D, Salles JP, Bonnerot C, Perret B, Record M (2004) PLD2 is enriched on exosomes and its activity is correlated to the release of exosomes. FEBS Lett 572(1-3):11-14. doi:10.1016/j.febslet.2004.06.082

53. Ghossoub R, Lembo F, Rubio A, Gaillard CB, Bouchet J, Vitale N, Slavik J, Machala M, Zimmermann P (2014) Syntenin-ALIX exosome biogenesis and budding into multivesicular bodies are controlled by ARF6 and PLD2. Nat Commun 5:3477. doi:10.1038/ncomms4477

54. Kooijman EE, Chupin V, de Kruijff B, Burger KN (2003) Modulation of membrane curvature by phosphatidic acid and lysophosphatidic acid. Traffic 4(3):162-174 
55. Alonso R, Rodriguez MC, Pindado J, Merino E, Merida I, Izquierdo M (2005) Diacylglycerol kinase alpha regulates the secretion of lethal exosomes bearing Fas ligand during activation-induced cell death of T lymphocytes. J Biol Chem 280(31):28439-28450. doi:10.1074/jbc.M501112200

56. Alonso R, Mazzeo C, Rodriguez MC, Marsh M, Fraile-Ramos A, Calvo V, Avila-Flores A, Merida I, Izquierdo M (2011) Diacylglycerol kinase alpha regulates the formation and polarisation of mature multivesicular bodies involved in the secretion of Fas ligand-containing exosomes in T lymphocytes. Cell Death Differ 18(7):1161-1173. doi:10.1038/cdd.2010.184

57. Mazzeo C, Calvo V, Alonso R, Merida I, Izquierdo M (2016) Protein kinase D1/2 is involved in the maturation of multivesicular bodies and secretion of exosomes in T and B lymphocytes. Cell Death Differ 23(1):99-109. doi:10.1038/cdd.2015.72

58. Maas SL, Breakefield XO, Weaver AM (2017) Extracellular vesicles: unique intercellular delivery vehicles. Trends Cell Biol 27(3):172-188. doi:10.1016/j.tcb.2016.11.003

59. Nolte-'t Hoen EN, Buermans HP, Waasdorp M, Stoorvogel W, Wauben MH, t Hoen PA (2012) Deep sequencing of RNA from immune cell-derived vesicles uncovers the selective incorporation of small non-coding RNA biotypes with potential regulatory functions. Nucleic Acids Res 40(18):9272-9285. doi:10.1093/nar/gks658

60. Pigati L, Yaddanapudi SCS, Iyengar R, Kim D-J, Hearn S, Danforth D, Hastings M, Duelli D (2010) Selective release of microRNA species from normal and malignant mammary epithelial cells. PLoS One 5(10):e13515-e13515

61. Hessvik NP, Phuyal S, Brech A, Sandvig K, Llorente A (2012) Profiling of microRNAs in exosomes released from PC-3 prostate cancer cells. Biochim Biophys Acta 1819(11-12):1154-1163

62. Villarroya-Beltri C, Gutierrez-Vazquez C, Sanchez-Cabo F, Perez-Hernandez D, Vazquez J, Martin-Cofreces N, MartinezHerrera DJ, Pascual-Montano A, Mittelbrunn M, SanchezMadrid F (2013) Sumoylated hnRNPA2B1 controls the sorting of miRNAs into exosomes through binding to specific motifs. Nat Commun 4:2980. doi:10.1038/ncomms3980

63. Cha DJ, Franklin JL, Dou Y, Liu Q, Higginbotham JN, Demory Beckler M, Weaver AM, Vickers K, Prasad N, Levy S, Zhang B, Coffey RJ, Patton JG (2015) KRAS-dependent sorting of miRNA to exosomes. eLife 4:e07197. doi:10.7554/eLife.07197

64. McKenzie AJ, Hoshino D, Hong NH, Cha DJ, Franklin JL, Coffey RJ, Patton JG, Weaver AM (2016) KRAS-MEK signaling controls Ago2 sorting into exosomes. Cell Rep 15(5):978-987. doi:10.1016/j.celrep.2016.03.085

65. Skog J, Wurdinger T, van Rijn S, Meijer DH, Gainche L, Curry WT, Carter BS, Krichevsky AM, Breakefield XO (2008) Glioblastoma microvesicles transport RNA and proteins that promote tumour growth and provide diagnostic biomarkers. Nat Cell Biol 10(12):1470-1476

66. Batagov AO, Kurochkin IV (2013) Exosomes secreted by human cells transport largely mRNA fragments that are enriched in the $3^{\prime}$-untranslated regions. Biol Direct 8:12. doi:10.1186/1745-6150-8-12

67. Bolukbasi MF, Mizrak A, Ozdener GB, Madlener S, Strobel T, Erkan EP, Fan JB, Breakefield XO, Saydam O (2012) miR-1289 and "Zipcode"-like sequence enrich mRNAs in microvesicles. Mol Ther Nucleic Acids 1:e10. doi:10.1038/mtna.2011.2

68. Buschow SI, Liefhebber JM, Wubbolts R, Stoorvogel W (2005) Exosomes contain ubiquitinated proteins. Blood Cells Mol Dis 35(3):398-403. doi:10.1016/j.bcmd.2005.08.005

69. Smith VL, Jackson L, Schorey JS (2015) Ubiquitination as a mechanism to transport soluble mycobacterial and eukaryotic proteins to exosomes. J Immunol 195(6):2722-2730. doi:10.4049/jimmunol.1403186
70. Cheng Y, Schorey JS (2016) Targeting soluble proteins to exosomes using a ubiquitin tag. Biotechnol Bioeng 113(6):1315-1324. doi:10.1002/bit.25884

71. Skotland T, Sandvig K, Llorente A (2017) Lipids in exosomes: current knowledge and the way forward. Prog Lipid Res 66:3041. doi:10.1016/j.plipres.2017.03.001

72. Record M, Poirot M, Silvente-Poirot S (2014) Emerging concepts on the role of exosomes in lipid metabolic diseases. Biochimie 96:67-74. doi:10.1016/j.biochi.2013.06.016

73. Pike LJ (2003) Lipid rafts: bringing order to chaos. J Lipid Res 44(4):655-667. doi:10.1194/jlr.R200021-JLR200

74. Lingwood D, Simons K (2010) Lipid rafts as a membraneorganizing principle. Science 327(5961):46-50. doi:10.1126/ science. 1174621

75. de Gassart A, Geminard C, Fevrier B, Raposo G, Vidal M (2003) Lipid raft-associated protein sorting in exosomes. Blood 102(13):4336-4344. doi:10.1182/blood-2003-03-0871

76. Kajimoto T, Okada T, Miya S, Zhang L, Nakamura S (2013) Ongoing activation of sphingosine 1-phosphate receptors mediates maturation of exosomal multivesicular endosomes. Nat Commun 4:2712. doi:10.1038/ncomms3712

77. Villarroya-Beltri C, Baixauli F, Mittelbrunn M, FernandezDelgado I, Torralba D, Moreno-Gonzalo O, Baldanta S, Enrich C, Guerra S, Sanchez-Madrid F (2016) ISGylation controls exosome secretion by promoting lysosomal degradation of MVB proteins. Nat Commun 7:13588. doi:10.1038/ncomms 13588

78. Villarroya-Beltri C, Baixauli F, Gutierrez-Vazquez C, SanchezMadrid F, Mittelbrunn M (2014) Sorting it out: regulation of exosome loading. Semin Cancer Biol 28:3-13. doi:10.1016/j. semcancer.2014.04.009

79. Sinha S, Hoshino D, Hong NH, Kirkbride KC, Grega-Larson NE, Seiki M, Tyska MJ, Weaver AM (2016) Cortactin promotes exosome secretion by controlling branched actin dynamics. J Cell Biol 214(2):197-213. doi:10.1083/jcb.201601025

80. Stenmark H (2009) Rab GTPases as coordinators of vesicle traffic. Nat Rev Mol Cell Biol 10(8):513-525. doi:10.1038/ $\operatorname{nrm} 2728$

81. Savina A, Vidal M, Colombo MI (2002) The exosome pathway in K562 cells is regulated by Rab11. J Cell Sci $115(\mathrm{Pt}$ 12):2505-2515

82. Koles K, Nunnari J, Korkut C, Barria R, Brewer C, Li Y, Leszyk J, Zhang B, Budnik V (2012) Mechanism of evenness interrupted (Evi)-exosome release at synaptic boutons. J Biol Chem 287(20):16820-16834. doi:10.1074/jbc.M112.342667

83. Ostrowski M, Carmo NB, Krumeich S, Fanget I, Raposo G, Savina A, Moita CF, Schauer K, Hume AN, Freitas RP, Goud B, Benaroch P, Hacohen N, Fukuda M, Desnos C, Seabra MC, Darchen F, Amigorena S, Moita LF, Thery C (2010) Rab27a and Rab27b control different steps of the exosome secretion pathway. Nat Cell Biol 12(1):19-30; sup pp 11-13. doi:10.1038/ncb2000

84. Hsu C, Morohashi Y, Yoshimura S, Manrique-Hoyos N, Jung S, Lauterbach MA, Bakhti M, Gronborg M, Mobius W, Rhee J, Barr FA, Simons M (2010) Regulation of exosome secretion by Rab35 and its GTPase-activating proteins TBC1D10A-C. J Cell Biol 189(2):223-232. doi:10.1083/jcb.200911018

85. Fruhbeis C, Frohlich D, Kuo WP, Amphornrat J, Thilemann S, Saab AS, Kirchhoff F, Mobius W, Goebbels S, Nave KA, Schneider A, Simons M, Klugmann M, Trotter J, Kramer-Albers EM (2013) Neurotransmitter-triggered transfer of exosomes mediates oligodendrocyte-neuron communication. PLoS Biol 11(7):e1001604. doi:10.1371/journal.pbio.1001604

86. Bobrie A, Krumeich S, Reyal F, Recchi C, Moita LF, Seabra MC, Ostrowski M, Thery C (2012) Rab27a supports exosomedependent and -independent mechanisms that modify the tumor microenvironment and can promote tumor progression. Cancer Res 72(19):4920-4930. doi:10.1158/0008-5472.can-12-0925 
87. Webber JP, Spary LK, Sanders AJ, Chowdhury R, Jiang WG, Steadman R, Wymant J, Jones AT, Kynaston H, Mason MD, Tabi Z, Clayton A (2015) Differentiation of tumour-promoting stromal myofibroblasts by cancer exosomes. Oncogene 34(3):290-302. doi:10.1038/onc.2013.560

88. Abrami L, Brandi L, Moayeri M, Brown MJ, Krantz BA, Leppla SH, van der Goot FG (2013) Hijacking multivesicular bodies enables long-term and exosome-mediated long-distance action of anthrax toxin. Cell Rep 5(4):986-996. doi:10.1016/j. celrep.2013.10.019

89. Jae N, McEwan DG, Manavski Y, Boon RA, Dimmeler S (2015) Rab7a and Rab27b control secretion of endothelial microRNA through extracellular vesicles. FEBS Lett 589(20 Pt B):3182-3188. doi:10.1016/j.febslet.2015.08.040

90. Worst TS, Meyer Y, Gottschalt M, Weis CA, von Hardenberg J, Frank C, Steidler A, Michel MS, Erben P (2017) RAB27A, $\mathrm{RAB} 27 \mathrm{~B}$ and VPS36 are downregulated in advanced prostate cancer and show functional relevance in prostate cancer cells. Int J Oncol. doi:10.3892/ijo.2017.3872

91. Loomis RJ, Holmes DA, Elms A, Solski PA, Der CJ, Su L (2006) Citron kinase, a RhoA effector, enhances HIV-1 virion production by modulating exocytosis. Traffic 7(12):1643-1653. doi:10.1111/j.1600-0854.2006.00503.x

92. Pfeffer SR (2007) Unsolved mysteries in membrane traffic. Annu Rev Biochem 76:629-645. doi:10.1146/annurev. biochem.76.061705.130002

93. Bonifacino JS, Glick BS (2004) The mechanisms of vesicle budding and fusion. Cell 116(2):153-166

94. Fader CM, Sanchez DG, Mestre MB, Colombo MI (2009) TIVAMP/VAMP7 and VAMP3/cellubrevin: two v-SNARE proteins involved in specific steps of the autophagy/multivesicular body pathways. Biochim Biophys Acta 1793(12):1901-1916. doi:10.1016/j.bbamcr.2009.09.011

95. Ruiz-Martinez M, Navarro A, Marrades RM, Vinolas N, Santasusagna S, Munoz C, Ramirez J, Molins L, Monzo M (2016) YKT6 expression, exosome release, and survival in non-small cell lung cancer. Oncotarget. doi:10.18632/oncotarget.9862

96. Wei Y, Wang D, Jin F, Bian Z, Li L, Liang H, Li M, Shi L, Pan C, Zhu D, Chen X, Hu G, Liu Y, Zhang CY, Zen K (2017) Pyruvate kinase type $\mathrm{M} 2$ promotes tumour cell exosome release via phosphorylating synaptosome-associated protein 23. Nat Commun 8:14041. doi:10.1038/ncomms14041

97. Hyenne V, Apaydin A, Rodriguez D, Spiegelhalter C, HoffYoessle S, Diem M, Tak S, Lefebvre O, Schwab Y, Goetz JG, Labouesse M (2015) RAL-1 controls multivesicular body biogenesis and exosome secretion. J Cell Biol 211(1):27-37. doi: $10.1083 /$ jcb. 201504136

98. Phuyal S, Skotland T, Hessvik NP, Simolin H, Overbye A, Brech A, Parton RG, Ekroos K, Sandvig K, Llorente A (2015) The ether lipid precursor hexadecylglycerol stimulates the release and changes the composition of exosomes derived from PC-3 cells. J Biol Chem 13(290):4225-4237. doi:10.1074/jbc. M114.593962

99. Glaser PE, Gross RW (1994) Plasmenylethanolamine facilitates rapid membrane fusion: a stopped-flow kinetic investigation correlating the propensity of a major plasma membrane constituent to adopt an HII phase with its ability to promote membrane fusion. Biochemistry 33(19):5805-5812

100. Strauss K, Goebel C, Runz H, Mobius W, Weiss S, Feussner I, Simons M, Schneider A (2010) Exosome secretion ameliorates lysosomal storage of cholesterol in Niemann-Pick type C disease. J Biol Chem 285(34):26279-26288. doi:10.1074/ jbc.M110.134775

101. Llorente A, van Deurs B, Sandvig K (2007) Cholesterol regulates prostasome release from secretory lysosomes in PC-3 human prostate cancer cells. Eur J Cell Biol 86(7):405-415
102. Savina A, Furlan M, Vidal M, Colombo MI (2003) Exosome release is regulated by a calcium-dependent mechanism in K562 cells. J Biol Chem 278(22):20083-20090. doi:10.1074/ jbc.M301642200

103. Kramer-Albers EM, Bretz N, Tenzer S, Winterstein C, Mobius W, Berger H, Nave KA, Schild H, Trotter J (2007) Oligodendrocytes secrete exosomes containing major myelin and stress-protective proteins: trophic support for axons? Proteom Clin Appl 1(11):1446-1461. doi:10.1002/prca.200700522

104. Tucker WC, Chapman ER (2002) Role of synaptotagmin in $\mathrm{Ca}^{2+}$-triggered exocytosis. Biochem $\mathrm{J}$ 366(Pt 1):1-13. doi:10.1042/bj20020776

105. Edgar JR, Manna PT, Nishimura S, Banting G, Robinson MS (2016) Tetherin is an exosomal tether. eLife. doi:10.7554/ eLife. 17180

106. Desdin-Mico G, Mittelbrunn M (2016) Role of exosomes in the protection of cellular homeostasis. Cell Adhes Migr. doi:1 0.1080/19336918.2016.1251000

107. Lehmann BD, Paine MS, Brooks AM, McCubrey JA, Renegar RH, Wang R, Terrian DM (2008) Senescence-associated exosome release from human prostate cancer cells. Cancer Res 68(19):7864-7871. doi:10.1158/0008-5472.can-07-6538

108. Beer L, Zimmermann M, Mitterbauer A, Ellinger A, Gruber F, Narzt MS, Zellner M, Gyongyosi M, Madlener S, Simader E, Gabriel C, Mildner M, Ankersmit HJ (2015) Analysis of the secretome of apoptotic peripheral blood mononuclear cells: impact of released proteins and exosomes for tissue regeneration. Sci Rep 5:16662. doi:10.1038/srep16662

109. Xiao X, Yu S, Li S, Wu J, Ma R, Cao H, Zhu Y, Feng J (2014) Exosomes: decreased sensitivity of lung cancer A549 cells to cisplatin. PLoS One 9(2):e89534. doi:10.1371/journal. pone. 0089534

110. King HW, Michael MZ, Gleadle JM (2012) Hypoxic enhancement of exosome release by breast cancer cells. BMC Cancer 12:421. doi:10.1186/1471-2407-12-421

111. Kanemoto S, Nitani R, Murakami T, Kaneko M, Asada R, Matsuhisa K, Saito A, Imaizumi K (2016) Multivesicular body formation enhancement and exosome release during endoplasmic reticulum stress. Biochem Biophys Res Commun 480(2):166-172. doi:10.1016/j.bbrc.2016.10.019

112. Boya P, Reggiori F, Codogno P (2013) Emerging regulation and functions of autophagy. Nat Cell Biol 15(7):713-720. doi: $10.1038 / \mathrm{ncb} 2788$

113. Fader CM, Sanchez D, Furlan M, Colombo MI (2008) Induction of autophagy promotes fusion of multivesicular bodies with autophagic vacuoles in k562 cells. Traffic 9(2):230-250. doi:10.1111/j.1600-0854.2007.00677.x

114. Sahu R, Kaushik S, Clement CC, Cannizzo ES, Scharf B, Follenzi A, Potolicchio I, Nieves E, Cuervo AM, Santambrogio L (2011) Microautophagy of cytosolic proteins by late endosomes. Dev Cell 20(1):131-139. doi:10.1016/j. devcel.2010.12.003

115. Alvarez-Erviti L, Seow Y, Schapira AH, Gardiner C, Sargent IL, Wood MJ, Cooper JM (2011) Lysosomal dysfunction increases exosome-mediated alpha-synuclein release and transmission. Neurobiol Dis 42(3):360-367. doi:10.1016/j.nbd.2011.01.029

116. Murrow L, Malhotra R, Debnath J (2015) ATG12-ATG3 interacts with Alix to promote basal autophagic flux and late endosome function. Nat Cell Biol 17(3):300-310. doi:10.1038/ ncb3112

117. Ponpuak M, Mandell MA, Kimura T, Chauhan S, Cleyrat C, Deretic V (2015) Secretory autophagy. Curr Opin Cell Biol 35:106-116. doi:10.1016/j.ceb.2015.04.016

118. Ejlerskov P, Rasmussen I, Nielsen TT, Bergstrom AL, Tohyama Y, Jensen PH, Vilhardt F (2013) Tubulin polymerizationpromoting protein (TPPP/p25alpha) promotes unconventional 
secretion of alpha-synuclein through exophagy by impairing autophagosome-lysosome fusion. J Biol Chem 288(24):1731317335. doi:10.1074/jbc.M112.401174

119. Nilsson P, Loganathan K, Sekiguchi M, Matsuba Y, Hui K, Tsubuki S, Tanaka M, Iwata N, Saito T, Saido TC (2013) Abeta secretion and plaque formation depend on autophagy. Cell Rep 5(1):61-69. doi:10.1016/j.celrep.2013.08.042

120. Settembre C, Fraldi A, Medina DL, Ballabio A (2013) Signals from the lysosome: a control centre for cellular clearance and energy metabolism. Nat Rev Mol Cell Biol 14(5):283-296. doi:10.1038/nrm3565

121. Van Deun J, Mestdagh P, Sormunen R, Cocquyt V, Vermaelen K, Vandesompele J, Bracke M, De Wever O, Hendrix A (2014) The impact of disparate isolation methods for extracellular vesicles on downstream RNA profiling. J Extracell Vesicles. doi:10.3402/jev.v3.24858

122. Thery C, Amigorena S, Raposo G, Clayton A (2006) Isolation and characterization of exosomes from cell culture supernatants and biological fluids. Curr Protoc Cell Biol Chapter 3:Unit 322. doi:10.1002/0471143030.cb0322s30

123. Coumans FAW, Brisson AR, Buzas EI, Dignat-George F, Drees EEE, El-Andaloussi S, Emanueli C, Gasecka A, Hendrix A, Hill AF, Lacroix R, Lee Y, van Leeuwen TG, Mackman N, Mager I, Nolan JP, van der Pol E, Pegtel DM, Sahoo S, Siljander PRM, Sturk G, de Wever O, Nieuwland R (2017) Methodological guidelines to study extracellular vesicles. Circ Res 120(10):1632-1648. doi:10.1161/circresaha.117.309417

124. Szatanek R, Baj-Krzyworzeka M, Zimoch J, Lekka M, Siedlar M, Baran J (2017) The methods of choice for extracellular vesicles (EVs) characterization. Int J Mol Sci 18(6):1153. doi:10.3390/ijms18061153

125. Koritzinsky EH, Street JM, Star RA, Yuen PS (2017) Quantification of exosomes. J Cell Physiol 232(7):1587-1590. doi: $10.1002 /$ jcp. 25387

126. Rupert DL, Claudio V, Lasser C, Bally M (2017) Methods for the physical characterization and quantification of extracellular vesicles in biological samples. Biochim Biophys Acta 1861(1 Pt A):3164-3179. doi:10.1016/j.bbagen.2016.07.028

127. Hosseini-Beheshti E, Pham S, Adomat H, Li N, Tomlinson Guns ES (2012) Exosomes as biomarker enriched microvesicles: characterization of exosomal proteins derived from a panel of prostate cell lines with distinct AR phenotypes. Mol Cell Proteom 11(10):863-885. doi:10.1074/mcp.M111.014845

128. Mathivanan S, Lim JW, Tauro BJ, Ji H, Moritz RL, Simpson RJ (2010) Proteomics analysis of A33 immunoaffinity-purified exosomes released from the human colon tumor cell line LIM1215 reveals a tissue-specific protein signature. Mol Cell Proteom 9(2):197-208. doi:10.1074/mcp.M900152-MCP200

129. Tauro BJ, Greening DW, Mathias RA, Ji H, Mathivanan S, Scott AM, Simpson RJ (2012) Comparison of ultracentrifugation, density gradient separation, and immunoaffinity capture methods for isolating human colon cancer cell line LIM1863-derived exosomes. Methods 56(2):293-304. doi:10.1016/j.ymeth.2012.01.002

130. Rupert DL, Shelke GV, Emilsson G, Claudio V, Block S, Lasser C, Dahlin A, Lotvall JO, Bally M, Zhdanov VP, Hook F (2016) Dual-wavelength surface plasmon resonance for determining the size and concentration of sub-populations of extracellular vesicles. Anal Chem. doi:10.1021/acs.analchem.6b01860

131. Grasso L, Wyss R, Weidenauer L, Thampi A, Demurtas D, Prudent M, Lion N, Vogel H (2015) Molecular screening of cancer-derived exosomes by surface plasmon resonance spectroscopy. Anal Bioanal Chem 407(18):5425-5432. doi:10.1007/ s00216-015-8711-5

132. Sina AA, Vaidyanathan R, Dey S, Carrascosa LG, Shiddiky MJ, Trau M (2016) Real time and label free profiling of clinically relevant exosomes. Sci Rep 6:30460. doi:10.1038/srep30460

133. Osteikoetxea X, Balogh A, Szabo-Taylor K, Nemeth A, Szabo TG, Paloczi K, Sodar B, Kittel A, Gyorgy B, Pallinger E, Matko J, Buzas EI (2015) Improved characterization of EV preparations based on protein to lipid ratio and lipid properties. PLoS One 10(3):e0121184. doi:10.1371/journal.pone.0121184

134. Melo SA, Luecke LB, Kahlert C, Fernandez AF, Gammon ST, Kaye J, LeBleu VS, Mittendorf EA, Weitz J, Rahbari N, Reissfelder C, Pilarsky C, Fraga MF, Piwnica-Worms D, Kalluri R (2015) Glypican-1 identifies cancer exosomes and detects early pancreatic cancer. Nature 523(7559):177-182. doi:10.1038/ nature 14581

135. Nolte-'t Hoen EN, van der Vlist EJ, Aalberts M, Mertens HC, Bosch BJ, Bartelink W, Mastrobattista E, van Gaal EV, Stoorvogel W, Arkesteijn GJ, Wauben MH (2012) Quantitative and qualitative flow cytometric analysis of nanosized cell-derived membrane vesicles. Nanomed Nanotechnol Biol Med 8(5):712_ 720. doi:10.1016/j.nano.2011.09.006

136. Sokolova V, Ludwig AK, Hornung S, Rotan O, Horn PA, Epple M, Giebel B (2011) Characterisation of exosomes derived from human cells by nanoparticle tracking analysis and scanning electron microscopy. Colloids Surf B 87(1):146-150. doi:10.1016/j.colsurfb.2011.05.013

137. Dragovic RA, Gardiner C, Brooks AS, Tannetta DS, Ferguson DJ, Hole P, Carr B, Redman CW, Harris AL, Dobson PJ, Harrison P, Sargent IL (2011) Sizing and phenotyping of cellular vesicles using Nanoparticle Tracking Analysis. Nanomed Nanotechnol Biol Med 7(6):780-788. doi:10.1016/j. nano.2011.04.003

138. Maas SL, Broekman ML, de Vrij J (2017) Tunable resistive pulse sensing for the characterization of extracellular vesicles. Methods Mol Biol (Clifton, NJ) 1545:21-33. doi:10.1007/978-1-4939-6728-5_2

139. Lerner N, Avissar S, Beit-Yannai E (2017) Extracellular vesicles mediate signaling between the aqueous humor producing and draining cells in the ocular system. PLoS One 12(2):e0171153. doi:10.1371/journal.pone.0171153 